\title{
DGF's årsmøde 2009 \\ - med temaet: Jagten på råstoffer
}

\section{Af Lars Hamberg, Dongenergy, Danmark}

Dansk Geologisk Forening afholdte 14. marts 2009 Årsmøde under overskriften: Jagten på råstoffer i den danske undergrund - nye metoder og geologisk viden.

Med et deltagerantal på 102 personer var rekorden fra tidligere år slået, og fra første foredrag af var tilhørendes engagement tydeligt - her var et emne, der havde stor interesse. De 12 foredrag dækkede et bredt spektrum af emner om råstoffer, fra grus, materialer og vand over mineraler til olie og gas, og blev præsenteret af en ligeså bred vifte af institutioner, firmaer og Regioner. Foredragene afdækkede nogle af de nye geofysiske og geologiske metoder, der an- vendes til kortlægningen af råstoffer, men belyste også nogle af de mange geologiske landvindinger og ny forståelse af geologien bag råstofudbredelsen. Resumé af foredrag kan ses på DGF's hjemmeside under Årsmøde 2009.

Foruden foredragene bød årsmødet på en posterudstilling, hvor speciale- og Ph.D.studerende kunne præsentere deres projekter. Meget flotte posters, der præsenterede emner og problemstillinger yderst professionelt. I pauserne var der således stor konkurrence mellem at se på posters, hilse på gamle og nye kolleger eller diskutere dagens emne. Under den efterfølgende livlige festmiddag for alle deltagere blev Danmarks Geologipris uddelt til Minik Rosing, Geologisk Museum, $\mathrm{KU}$, for hans banebrydende dokumentation af og teorier om Jordens tidlige udvikling (mere herom på s. 21).

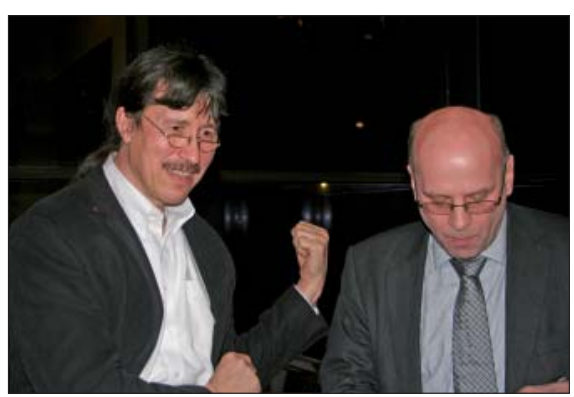

Prismodtageren Minik Rosing i hyggelig samtale med vicedirektør Flemming Getreuer Christiansen, GEUS, der overrakte prisen. (Foto: Henrik Højmark Thomsen, GEUS)

Foreningen takker årsmødets sponsorer DONGenergy, COWI, Gontmij/Carl Bro, Shell, Mcrsk, Rambøll, Baker Huges. 